\title{
URGENSI KETERAMPILAN SOSIAL PUSTAKAWAN PADA LAYANAN REFERENSI DALAM MENGHADAPI GLOBALISASI INFORMASI
}

\author{
Iwin Ardyawin*
}

Pengutipan: Ardyawin, I. (2017). Urgensi keterampilan sosial pustakawan pada layanan referensi dalam menghadapi globalisasi informasi. Khizanah Al-Hikmah : Jurnal Ilmu Perpustakaan, Informasi, dan Kearsipan, 5(1), 129-139.

DOI: http:/ / dx.doi.org/10.24252/kah.v5i1a12

\author{
*Mahasiswa Program Pascasarjana UIN Sunan Kalijaga Yogyakarta \\ iwinardyawin@gmail.com
}

\begin{abstract}
ABSTRAK
Perpustakaan merupakan sarana penunjang bagi kegiatan belajar yang berfungsi sebagai pusat informasi untuk pengembangan pendidikan dan penelitian. Perpustakaan dituntut untuk dapat menyediakan pelayanan berbentuk referensi secara tepat dan cepat dalam memberikan informasi. Layanan perpustakaan merupakan ujung tombak dari kegiatan perpustakaan karena di dalamya terjadi pola interaksi antara pustakawan dengan berbagai macam pengguna perpustakaan. Komunikasi yang terjadi antara pustakawan dengan pengguna dalam pelayanan dimulai ketika adanya perhatian pustakawan terhadap kebutuhan pengguna. Teknologi memungkinkan kita mengakses sumber informasi yang berada di luar perpustakaan dan memberikan cara yang lebih mudah, konsekuensinya pustakawan harus tetap memainkan perannya sebagai manager informasi dan memberikan pelayanan informasi terbaik. Pelayanan referensi pada masa mendatang memungkinkan pustakawan untuk lebih pro-aktif dengan adanya teknologi baru, generasi baru, sehingga perpustakaan dituntut untuk membuat pelayanan cepat dan dinamis. Sudah semestinya keterampilan seorang pustakawan harus memiliki kreatifitas dan inovasi terhadap informasi saat sekarang ini, karena kemajuan sebuah perpustakaan tergantung bagaimana pustakawan terampil dalam memberikan layanan yang maksimal kepada pengguna sehingga hasil dari keterampilan pustakawan dapat memberikan rangsangan terhadap pola pikir pengguna terhadap perpustakaan.
\end{abstract}

Kata kunci : Keterampilan sosial, pustakawan, layanan referensi, globalisasi informasi

\section{ABSTRACT}

Library is a support tool for study that has function as central information for education and research development. Library has to ready to give service like reference quickly and exactly. Library service is the core of library activity because there is interaction between librarian and users. Their interaction happen when librarian attention to user necessity. Through technology may be we can get source information from outside library, but librarian still has to play their rule as information manager and to give the best information service. In the future, the service reference will make librarian more active because of new technology and new generation, so the librarian has to have quick and dynamic service. Apparently librarian has to creative and innovative to information, because developing of library depends on librarian that seen by their maximal service to user, so the result of librarian ability can make good respond of user.

Key words: Social ability, librarian, reference service, information globalisation 


\section{PENDAHULUAN}

Perpustakaan merupakan agen perubahan (agen of change) atau agen pembangunan dan agen budaya. Maksudnya bahwa perpustakaan itu menjadi tempat rujukan dan sumber informasi (Sutarno, 2006, 271). Bahwa perpustakaan harus berperan aktif dalam memberikan informasi kepada pengguna sehingga dampak dari informasi yang update setiap waktu, dapat memberikan solusi terhadap apa yang menjadi permasalahan yang ada di tengah masyarakat di situlah perpustakaan harus memberikan peran yang sangat penting sebagai solusi dari apa yang menjadi permasalahan tersebut. Perpustakaan merupakan suatu sarana penunjang bagi kegiatan belajar yang berfungsi sebagai pusat informasi untuk pengembangan pendidikan dan penelitian. Perpustakaan dituntut untuk dapat menyediakan pelayanan berbentuk referensi secara tepat dan cepat sesuai masing-masing kebutuhan pengguna.

Layanan perpustakaan merupakan ujung tombak dari kegiatan perpustakaan karena di dalamnya terjadi pola interaksi antara pustakawan dengan berbagai macam pengguna perpustakaan. Komunikasi yang terjadi antara pustakawan dengan pengguna dalam pelayanan dimulai ketika adanya perhatian pustakawan terhadap kebutuhan pengguna. Pada saat-saat tersebut, peran pustakawan sebagai konsultan informasi sangat besar artinya, karena berhubungan langsung dengan pengguna yang membutuhkan informasi. Inilah kunci terjalinnya hubungan, baik antara pustakawan dengan pengguna karena kemampuan pustakawan dalam menyampaikan informasi dapat menumbuhkan kepercayaan pengguna terhadap pustakawan.

Istilah dari referensi berkembang dari tujuan utama perpustakaan yaitu memberikan informasi. Karena informasi yang dimiliki sering kurang memenuhi kebutuhan, perpustakaan mengarahkan mereka lebih lanjut pada lembaga ataupun sumber lain yang lebih tepat, bahkan dapat juga bertindak lebih jauh hingga pustakawanlah yang membuat perjanjian dengan lembaga lain tersebut untuk memperoleh bahan-bahan yang dibutuhkan untuk kepentingan si penanya.

Memasuki era informasi seperti saat sekarang ini, layanan referensi memainkan peranan yang penting sebagai penunjuk jalan atau mediator antara pengguna dan sumber informasi maupun informasi itu sendiri. Melalui layanan referensi ini, perpustakaan dituntut untuk menggali, menelusur keberadaan informasi dari mana saja, menyuguhkan dalam format cetak atau non cetak sesuai dengan permintaan pengguna. Format yang diminta juga dapat berkisar dalam bentuk data bibliografi, catatan hingga ringkasan, laporan, ulasan maupun tabulasi sehingga kebutuhan informasi pengguna perpustakaan dapat selalu ter-update tanpa harus menunggu keluhan dari pengguna itu sendiri.

Dalam melayani kebutuhan pengguna yang heterogen dari segi kesadaran akan informasi, kebutuhan, maupun tingkat pengertian, perpustakaan diharapkan pula untuk dapat memberikan jasa referensi yang beraneka ragam, sesuai dengan tujuan dan kebutuhan masingmasing. Layanan yang diberikan dapat bervariasi dari sekedar menjawab pertanyaan, mengarahkan ke sumber lain, 
menuntun cara menggunakan perpustakaan, menelusur informasi bagi kepentingan pengguna baik atas permintaan ataupun inisiatif perpustakaan serta mengadakan kegiatankegiatan promosi untuk tujuan penjangkauan masyarakat pengguna yang lebih luas (Rahardjo, 1996, 7).

Di dukung oleh seluruh fasilitas, hubungan dengan pihak-pihak lain yang berkaitan serta seluruh koleksi perpustakaan, jenis-jenis layanan referensi di atas dapat dilaksanakan secara menyeluruh oleh suatu unit layanan referensi atau terpisah-pisah menjadi beberapa unit yang lebih khusus. Demikian pula, semua jenis layanan referensi tersebut dapat ditangani oleh satu atau beberapa ahli secara keseluruhan atau secara sendiri-sendiri.

\section{LAYANAN REFERENSI}

Pelayanan referensi adalah salah satu kegiatan pokok yang dilakukan di perpustakaan, yang__. khusus melayangkan/menyajikan koleksi referensi kepada para pemakai/pengunjung perpustakaan. Suatu kegiatan pelayanan untuk membantu para pemakai/pengunjung perpustakaan menemukan/mencari informasi dengan cara:

a. Menerima pertanyaan-pertanyaan dari para pemakai/pengunjung perpustakaan dan kemudian menjawab dengan menggunakan koleksi referensi.

b. Memberikan bimbingan untuk menemukan koleksi referensi yang diperlukan untuk menemukan/mencari informasi yang dibutuhkan oleh pemakai/pengunjung.

c. Memberikan bimbingan kepada para pemakai/pengunjung perpustakaan tentang bagaimana menggunakan setiap bahan pustaka koleksi referensi (Sumardji, 1992, 11).

Pelayanan referensi merupakan bantuan yang diberikan kepada pemustaka secara perorangan ketika dia mencari informasi. Bantuan ini dilakukan oleh pustakawan terlatih khusus untuk memenuhi kebutuhan informasi pemustaka, baik secara langsung bertatap muka, melalui telepon, maupun secara elektronik. Pustakawan tidak hanya menjawab pertanyaan substantif, tetapi juga membimbing pemustaka untuk memilih dan menggunakan sarana yang tepat untuk penelusuran informasi. Dia mengarahkan pemustaka ke sumber informasi, membantu mereka mengevaluasi, bahkan merujuk pada sumber di luar perpustakaan. Kepustakawanan referensi merupakan kegiatan profesi yang khusus memfokuskan pada referensi (Widyawan, 2012, 3).

\section{DASAR-DASAR PELAYANAN REFERENSI \\ a. Tujuan Referensi}

Pemustaka dapat meminta bantuan staf di meja referensi untuk membantu mencari informasi. Dengan menggunakan wawancara referensi terstruktur, pustakawan bekerja untuk memastikan kebutuhan pemustaka, dan menentukan sumber informasi yang tepat. Jika kita meminjam istilah medis, pustakawan referensi mendiagnosis dan menangani kesenjangan informasi.

Tujuan pelayanan referensi adalah untuk memenuhi kebutuhan pemustaka mencakup mencari informasi menggunakan sumber informasi dan menggunakan sumber informasi yang ada di perpustakaan. Sebagai lembaga selalu 
memberikan pelayanan secara adil dan tidak memihak. Dia mempromosikan nilai informasi untuk pemecahan masalah kehidupan sehari-hari, hiburan, dan pencerahan (Widyawan, 2012, 5).

Adapun tujuan dari referensi sebagai berikut:

1) Mengarahkan pemakai/pengunjung perpustakaan menemukan informasi yang dibutuhkan dengan tepat dan cepat.

2) Memampukan pemakai/pengunjung perpustakaan menelusur informasi dengan menggunakan berbagai pilihan sumber informasi yang lebih luas.

3) Memampukan pemakai/pengunjung perpustakaan menggunakan setiap koleksi referensi dengan lebih tepat guna (Sumardji, 1992, 11).

Oleh karena itu, seorang staf referensi perlu memahami bahwa meja informasi adalah bagian penting sebuah perpustakaan. Pelayanan yang diberikan di meja informasi berbeda bergantung dari jenis perpustakaan, sumber yang ada dan staf.

Misi perpustakaan pada umumnya adalah menyentuh masyarakat yang membutuhkan informasi, baik yang tersimpan di perpustakaan, di tempat lain yang di capai secara online, dan yang lebih unik adalah mereka yang tidak pernah berpikir untuk menggunakan perpustakaan akan disambut dengan tangan terbuka dan dibuat nyaman (Widyawan, 2012, 5).

\section{b. Fungsi Referensi}

Ada beberapa fungsi dari referensi yaitu sebagai berikut:

1) Informasi
Memberikan jawaban atas pertanyaanpertanyaan tentang informasi yang dibutuhkan oleh para pemakai/pengunjung perpustakaan.

\section{2) Bimbingan}

Memberikan bimbingan kepada para pemakai/pengunjung perpustakaan untuk mencari/menemukan bahan pustaka dalam kelompok koleksi referensi yang tepat sesuai dengan bidang masingmasing, dan bagaimana pula cara menggunakannnya untuk mencari/menemukan informasi yang dikehendaki.

3) Pemilihan/Penilaian

Memberikan petunjuk/pengertian tentang bagaimana cara memilih/menilai bahan pustaka dalam kelompok koleksi referensi yang bermutu dan berbobot ilmiah agar diperoleh sumber informasi yang berdaya guna maksimal.

\section{c. Penunjang Referensi}

Untuk dapat mencapai tujuan dan berfungsi seperti tersebut di atas, suatu Unit Pelayanan Referensi di perpustakaan perlu ditunjang:

1) Petugas pelayanan referensi yang cakap, dengan syarat seperti berikut:

Merupakan petugas tetap pada Unit Pelayanan Referensi,

> Bersikap ramah dan berkebiasaan tekun, cermat dan telaten,

$>$ Bersikap terbuka dan selalu siap memberikan bantuan kepada para pemakai/pengunjung perpustakaan,

$>$ Memiliki pengetahuan umum yang cukup luas,

> Mengetahui berbagai jenis bahan pustaka yang termasuk dalam 
kelompok koleksi referensi dan bagaimana pula cara penggunaan masing-masing,

> Mampu memberikan bimbingan/ petunjuk praktis kepada para pemakai/pengunjung perpustakaan dalam upaya memilih dan menggunakan koleksi referensi yang di kehendaki sesuai dengan bidang pengetahuan masingmasing.

2) Koleksi referensi yang lengkap dan berbobot ilmiah, yang disajikan dalam rak terbuka yang rapih, bersih, dan mudah dicapai.

3) Perabot dan perlengkapan perpustakaan yang lengkap dan tata ruang yang nyaman serta aman untuk tempat studi para pemakai/pengunjung perpustakaan.

4) Kerja sama yang baik dan saling menguntungkan antar perpustakaan dalam bidang pelayanan referensi (menyediakn sumber informasi) kepada para pemakai/pengunjung perpustakaan (Sumardji, 1992, 12-13).

\section{d. Macam-macam Kegiatan Pelayanan Referensi}

Kegiatan pelayanan referensi dapat dibagi menjadi 2 jenis kegiatan pokok dengan kegiatannya masing-masing seperti berikut:

1) Kegiatan Pokok Pelayanan Referensi

a) Memberikan informasi yang bersifat umum, baik mengenai perpustakaan yang bersangkutan pada umumnya maupun khususnya mengenai Unit Pelayanan Referensinya.

b) Memberikan informasi yang bersifat spesifik/khusus, yang untuk itu diperlukan bahan koleksi referensi yang ada di perpustakaan yang bersangkutan dan bahkan di perpustakaan lain, atau berkonsultasi (minta informasi) kepada para pustakawan di perpustakaan-perpustakaan tersebut.

c) Memberikan bantuan menelusur informasi sampai ditemukan informasi yang dibutuhkan para pemakai/pengunjung baik melalui bahan pustaka koleksi referensi perpustakaan yang bersangkutan maupun perpustakaan yang lain.

d) Memberikan bantuan untuk menelusur bahan pustaka koleksi referensi yang diperlukan oleh para pemakai/pengunjung perpustakaan dengan menggunakan katalog, bibliografi, komputer (kalau ada), dan alat-alta penelusuran lainnya.

e) Memberikan bantuan pengarahan kepada para pemakai/pengunjung perpustakaan untuk menemukan pokok-pokok bahasan pengetahuan tertentu yang terdapat di dalam bahan pustaka koleksi referensi.

f) Memberikan bimbingan (kalau perlu secara klasikal dan formal) kepada para pemakai/pengunjung perpustakaan untuk mengenal berbagai jenis bahan pustaka koleksi referensi, mengetahui bagaimana cara menggunakan masing-masing, dan mengetahui cara memilih yang tepat menemukan/mencari informasi yang mereka masing-masing butuhkan.

2) Kegiatan Penunjang Pelayanan Referensi

a) Menjalin hubungan kerja sama yang baik dengan perpustakaan 
lain dan/atau lembaga pemberi layanan jasa informasi lain, dalam bidang kegiatan pemberian layanan jasa penggunaan informasi.

b) Menyelenggarakan pendidikan secara formal dan klasikal untuk memberikan pengetahuan dan keterampilan kepada para pemakai/pengunjung

perpustakaan tentang bagaimana cara memilih bahan pustaka koleksi referensi yang tepat dan berbobot ilmiah sesuai dengan kebutuhan, dan tentang bagaimana pula cara mencari/menemukan informasi yang dikehendaki.

c) Memperkenalkan

koleksi perpustakaan kepada masyarakat umum dengan cara:

Menyelenggarakan pameran perpustakaan (kalau perlu bekerja sama dengan para penerbit dan para agen penyalur barang-barang/alat-alat yang bersangkutan dengan teknologi informasi).

$>$ Menerbitkan bibliografis perpustakaan yang berisi bahan koleksi apa saja yang dimiliki perpustakaan yang bersangkutan.

$>$ Khusus bagi para pemakai/pengunjung

perpustakaan di samping dengan cara-cara tersebut di atas, juga dengan cara selalu men-display (memajang) setiap bahan pustaka yang baru diterima pada almari display.

> Mengumpulkan, mengolah, dan menyajikan statistik pelaksanaan kegiatan pelayanan referensi dalam bentuk tabel-tabel dan grafik-grafik, untuk digunakan sebagai bahan informasi ataupun sebagai bahan untuk pembuatan laporan (Sumardji, 1992, 13-15).

\section{EVOLUSI PELAYANAN REFERENSI}

Dengan digunakannya teknologi informasi di perpustakaan, kebanyakan perpustakaan masa kini adalah lembaga hibrida yang menyimpan dokumen digital maupun tradisional atau tercetak. Dalam keadaan seperti ini, pustakawan referensi akan memainkan perannya sebagai seorang navigator, yang akan menemani dan membimbing pemustaka untuk mendapatkan sumber informasi yang bermanfaat membuka cakrawala pengetahuan luas tanpa batas.

Teknologi memungkinkan kita mengakses sumber informasi yang berada di luar perpustakaan dan memberikan cara yang lebih mudah, konsekuensinya pustakawan harus tetap memainkan perannya sebagai manager informasi dan memberikan pelayanan informasi terbaik. Koleksi dan pelayanan perpustakaan akan lebih mudah digunakan, dan perpustakaan akan selalu berusaha memberikan nilai tambah informasi yang diperlukan pemustaka pada sumber yang tersedia yang dikelola dengan baik. Banyak hal-yang terkait dengan perubahan pelayanan referensi. Menurut Cassel dalam catatannya, beberapa hal tersebut, antara lain sebagai berikut:

\section{a) Perubahan koleksi referensi}

Bahan-bahan referensi baru perlu ditambahkan untuk koleksi perpustakaan, dan banyak di antaranya lebih dari satu format. Perpustakaan harus lebih cermat dalam memilih sumber-sumber informasi itu. Oleh karena itu, anggaran perlu dipersiapkan dengan matang, karena sumber-sumber informasi bisa diluar jangkauan anggaran, atau jauh dari perkiraan, karena di Indonesia 
pengadaannya masih menggunakan nilai tukar dolar.

b) Pola penyajian pelayanan

Pola pelayanan referensi harus dikembangkan untuk menyesuaikan dengan sumber elektronik sehingga kepiawaian pustakawanan dapat dimanfaatkan secara maksimal dan pelayanan berjalan efektif. Langkah ini termasuk menyiapkan pustakawan profesional yang siap di meja referensi sehingga dapat memberikan bantuan lebih maksimal.

\section{c) Ruangan}

Ruangan referensi pun perlu dirancang agar pelayanan bisa berlangsung lancar dengan menyediakan beberapa terminal komputer.

\section{d) Pengenalan sumber referensi baru}

Pustakawan referensi bersamaan dengan pustakawan yang bekerja dibagian lain perlu dilatih untuk mengenal sumber referensi baru. Kecuali jika para staf mudah memahami dan mau mengeksplorasi sumber elektronik baru. Tindakan ini penting karena pada akhirnya para staf ini akan memberikan bimbingan kepada para pemustaka.

Beberapa perubahan mungkin dapat dilaksanakan dengan mudah, tetapi yang lain memerlukan perangkat lunak dan perangkat keras yang canggih. Perubahan teknologi yang cepat menyebabkan kebanyakan perpustakaan sulit untuk mengikutinya. Komputer yang konstan diperbarui untuk program-program yang semakin canggih. Sumber-sumber informasi elekronik yang dihasilkan tahun lalu, bisa jadi diganti dengan sumber informasi yang lain atau setidaknya alternatif baru atau produk yang diperbarui. Perpustakaan harus siap dengan perubahan-perubahan yang terkait dengan teknologi, finansial, politik, dan budaya (Widyawan, 2012, 6-8).

\section{PELAYANAN REFERENSI PADA ERA GLOBALISASI INFORMASI}

Pelayanan referensi pada masa mendatang memungkinkan pustakawan untuk lebih pro-aktif dengan adanya teknologi baru, generasi baru, sehingga perpustakaan dituntut untuk membuat pelayanan cepat dan dinamis seperti mengembangkan blog perpustakaan atau twitter untuk mempromosikan pelayanan, menggunakan perangkat lunak Wiki untuk melibatkan pemustaka dalam menyusun web, membuat webcast/podcast, mengintegrasikan katalog dengan sistem online lain untuk kelancaran pengiriman dan mendaftar umpan RSS (Really Simple Syndication) untuk mengikuti konsepkonsep baru. Webcast adalah peresentasi media yang disebarkan melalui internet dengan menggunakan teknologi media streaming untuk menyebarkan sumber konten tunggal kepada beberapa pendengar atau pemirsa. Pada hakikatnya webcasting adalah menyiarkan melalui internet. Sementara podcast (non-streamed webcast) adalah sejumlah media digital (audio atau video) yang disiarkan secara episode dan sering diunduh melalui sindikasi web.

Kemungkinan pelayanan informasi pada masa mendatang tidak banyak menekankan lokasi pelayanan referensi dan pelayanan jarak jauh dengan tempat pelayanan yang berbeda atau dengan perpustakaan cabang. Para pemustaka bisa memperolesh pelayanan itu melalui pesan singkat, atau saran lainnya. Bisa juga pustakawan memanfaatkan media campuran yang menekankan pada 
kolaborasi dan partisipatif. Namun demikian, masa depan pelayanan referensi akan bergantung pada unsurunsur yang diajukan oleh Eilen Abel berikut ini:

\section{a. Pemustaka}

Pemustaka yang dihadapi
pustakawan referensi memang
mempunyai latar belakang yang
Dari geragam.
dikelompokkan pada anak-anak, remaja, dan orang tua. Dari golongan ini, pemustaka remaja termasuk generasi digital native yang sejak kecil telah akrab dengan teknologi informasi dan digital. Pemustaka zaman sekarang sudah terbiasa dengan banyaknya pilihan dalam kehidupan sehari-hari, baik itu makanan, komputer, video games, televisi, pesan pencari, dan lain sebagainya. Kemungkinan pada masa mendatang akan lebih banyak pemustaka yang media Savoy, mempunyai kecerdasn media dalam arti memahami bagaimana media itu bekerja dan mampu menggunakan dan memanipulasi media untuk kepentingan mereka. Mereka kebanyakan mempunyai kekuasaan dan hubungan baik dengan mereka. Bahkan mereka mempunyai humas dan manager untuk media.

\section{b. Sumber Informasi}

Kemungkinan pada masa mendatang, sumber-sumber informasi akan lebih bervariasi karena munculnya hypertext dan hypermedia. Banyak vendor menyediakan situs web gratis sehingga perkembangan sumber informasi semakin kita rasakan. Banyak perpustakaan digital memberikan peluang kepada orang untuk mendaftar pada perpustakaan digital sendiri.
Pangkalan data naskah utuh (full text) juga banyak tersedia, baik yang menggunakan skala gratis seperti Indonesia Scientific Digital Journal (ISDJ), Digital Open Access Journal (DOAJ), Questia (http://www.questia.com), Project Gutenberg, maupun skala berbayar seperti pangkalan data komersial, atau setengah gratis seperti High Beam Research (http://www.highbeam.com/Library/in dex.asp). Perlu kita catat bahwa Google sejak lama menyediakan pelayanan, selain mesin pencari seperti Google Scholar (http://scholar.google.com), tetapi juga Google Translate, Google Maps, dan Prototype Proyek Google Labs (http://labs.google.com).

\section{c. Teknologi}

Dalam kehidupan sekarang ini, web merupakan sesuatu yang lumrah dan hampir semua orang mengenalnya. Terasa ada kecenderungan adanya kepuasan masyarakat pada kinerja mesin pencari dengan munculnya anekdot "Tanya saja sama Mbah Google", tanpa mengetahui bagaimana mesin pencari itu bekerja. Bisa saja ini merupakan cerminan kepuasan masyarakat pada mesin pencari.

\section{d. Perpustakaaan}

Perpustakaan pada masa mendatang kemungkinan akan menyimpan koleksi tercetak maupun digital. Perpustakaan akan menghadapi masalah ruang penyimpanan sumber informasi tercetak dan harus menyesuaikan dengan perubahan sosial dan teknologi sekaligus pertumbuhan buku. Perpustakaan akan terfokus pada penyediaan informasi dan pelayanan yang bermanfaat. Masalah sirkulasi, pengadaan, dan pendanaan, perpustakaan sekarang akan lebih mengemuka.

\section{e. Pustakawan}


Pustakawan haruslah luwes dan selalu siaga untuk menghadapi perubahan, dia harus peka terhadap perubahan lingkungan, berpandangan luas, dan banyak melihat perkembangan pelayanan referensi di luar perpustakaan tempat mereka bekerja (Widyawan, 2012, 11-15).

\section{KETERAMPILAN DAN CARA BERKOMUNIKASI PUSTAKAWAN DALAM MEMBERIKAN LAYANAN REFERENSI KEPADA PENGGUNA}

Pustakawan selaku pelayan jasa informasi dapat berkomunikasi dengan pengguna yang datang ke perpustakaan untuk menanyakan, mencari dan menemukan informasi. Untuk memberikan pelayanan kepada pengguna, pustakawan harus membangun komunikasi yang baik.

Menurut Effendy $(1993,9)$ komunikasi yang baik yaitu "Komunikasi tidak hanya informatif, yakni agar orang lain mengerti dan tahu, tetapi tidak juga persuasif, yakni agar orang lain bersedia menerima suatu paham atau keyakinan melakukan suatu perbuatan atau kegiatan dan lainlain.

Rumusan di atas menunjukan bahwa komunikasi tidak hanya sebuah kegiatan mentransfer informasi atau pasar, tetapi juga cara berkomunikasi yang harus menjadi perhatian bagi seorang pustakawan ketika melakukan pelayanan terhadap pengguna, agar pengguna merasa terlayani, dihargai sebagai individu maupun sebagai makhluk sosial.

Oleh karena itu pustakawan sesungguhnya harus merasa tertarik untuk mengenal pengguna secara lebih dekat selaku individu. Mengenal individu secara lebih dekat menjadi sebuah tuntutan terhadap pustakawan dalam memberikan layanan jasa informasi.

Dengan mengenal perilaku individu, maka dengan mudah pula pustakawan dapat berkomunikasi dengan individuindividu selaku pengguna jasa perpustakaan. Sebaliknya pustakawan dituntut untuk menunjukan komunikasi yang baik dalam memberikan pelayanan kepada para pengguna, sehingga pesan yang diterima oleh pengguna menjadi jelas dan dapat mempengaruhi pengguna, dapat melakukan perbuatan atau kegiatan sesuai dengan ketentuan-ketentuan dan sesuai dengan yang dikehendaki oleh pustakawan. Jadi diharapkan seorang pustakawan dalam memberikan pelayanan harus komunikatif. Seorang pustakawan yang komunikatif, yaitu pustakawan yang mampu dan memahami bagaimana cara berkomunikasi yang baik kepada para penggunanya (Nurhadi, 1980, 10).

Sudah semestinya keterampilan seorang pustakawan harus memiliki kreatifitas dan inovasi terhadap kebutuhan pengguna informasi saat sekarang ini karena bagaimanapun juga kemajuan sebuah perpustakaan tergantung bagaimana pustakawan terampil dalam memberikan layanan yang maksimal kepada pengguna sehingga hasil dari keterampilan pustakawan dapat memberikan rangsangan terhadap pola pikir pengguna terhadap perpustakaan agar dapat menggunakan perpustakaan sebagai sumber informasi sehingga pelan namun pasti perpustakaan akan berkembang dengan semakin majunya perkembangan teknologi sehingga pustakawan harus memiliki kesadaran tentang betapa pentingnya memberikan yang terbaik kepada pengguna dengan 
cara yang sesuai dengan kemampuan pustakawan.

\section{KEBUTUHAN PENGGUNA DALAM PENCARIAN INFORMASI}

Sebagaimana diketahui bahwa manusia dalam kondisi apapun akan memerlukan informasi. Sedangkan kualitas dan ragam informasi yang diperlukan sangat tergantung pada motivasi dan tujuan masing-masing orang. Untuk informasi literature tentunya diperlukan oleh mereka yang berpendidikan menengah ke atas. Oleh karena itu pustakawan sebagai penyaji informasi perlu memahami tingkat kebutuhan mereka tentang informasi keilmuan, antara lain:

a. Memerlukan

informasi sekilas/Catching up information

Kelompok ilmuan yang mencari informasi ke perpustakaan hanya bersifat sekilas misalnya hanya dengan melihatlihat judul buku atau majalah. Cara ini untuk memenuhi kebutuhan orientasi masalah yang akan ditulis atau diteliti. Serta untuk menambah wawasan informasi yang sewaktu-waktu diperlukan

b. Memerlukan informasi untuk kepentingan rutin/Everyday need

Mereka yang memerlukan jenis informasi ini untuk menyelesaikan tugastugas mereka setiap hari yang memang memerlukan informasi. Mereka itu adalah mahasiswa, penulis, pendidik (guru, dosen) dan lainnya. sebab memang tugas dan pekerjaan mereka selalu memerlukan informasi sewaktu-waktu

c. Memerlukan informasi mutakhir/ Current information
Para peneliti, ilmuwan, mahasiswa, pengamat dan penentu kebijakan umumnya memerlukan informasi terbaru. Kebaharuan informasi yang diterima akan menunjukkan kualitas informasi itu sendiri. Dalam hal ini hendaknya pustakawan tanggap terhadap kebutuhan informasi semacam ini untuk memberikan pelayanan informasi sebaik mungkin. Sebab untuk kepentingan seminar, mengajar, dan bentuk-bentuk pengembangan ilmu pengetahuan yang lain sangat memerlukan teori, pengalaman, dan penemuan baru.

d. Kebutuhan informasi yang mendalam/Executive information

Informasi yang terbaru, bisa diambil contoh para peneliti, mahasiswa S1, S2 atau mahasiswa D3 sangat memerlukan informasi yang mendalam dalam bidang mereka. Informasi ini dapat dicari dan diarahkan untuk mencari pada sumbersumber informasi seperti ensiklopedia, makalah seminar, laporan penelitian, karya akademik, dan lainnya. Dari yang telah diuraikan di atas maka pustakawan dituntut untuk mengetahui apa kebutuhan penggguna dalam pencarian informasi agar dapat memberikan pelayanan informasi sebaik mungkin yang dapat memuaskan pengguna dalam pencarian informasinya (Listiani, 2001, 13).

\section{KESIMPULAN}

Pustakawan sudah semestinya memberikan kontribusinya kepada pemustaka sehingga keterampilan setiap pustakawan harus mampu melihat permasalahan-permasalahan di tengah masyarakat pengguna informasi dan dapat memberikan solusi terhadap masalah itu. Pustakawan dalam memberikan layanan referensi jasa perpustakaan kepada pengguna dituntut 
untuk memberikan pelayanan yang maksimal, oleh karena itu pustakawan harus memahami nilai-nilai sikap dan perilaku, antara lain adanya perhatian yang baik dan menyenangkan, berpenampilan yang sopan dan cara berkomunikasi yang baik sehingga dalam layanan referensi timbul hubungan yang baik antara pustakawan dan pengguna agar dalam memberikan informasi sesuai dengan keinginan pengguna. Sehingga perpustakaan harus selalu peka terhadap perkembangan informasi-informasi yang terjadi.

Koleksi dan pelayanan perpustakaan akan lebih mudah digunakan, dan perpustakaan akan selalu berusaha memberikan nilai tambah informasi yang diperlukan pemustaka pada sumber yang tersedia yang dikelola dengan baik.

\section{DAFTAR PUSTAKA}

Rahardjo, A. I. (1996). “Pelatihan Terpadu Manajemen Perpustakaan

Modern". Universitas Kristen Petra, Pusat Pendidikan Berkelanjutan.

Effendy, O. U. (1993). Dinamika Komunikasi, Bandung: Remaja Rosda Karya.

Listiani, W. (2001). “Pustakwan Berprofesi Konsultan", Media Pustakawan Volume 8 Nomor 2.

Muchyidin, A. (1980). Pelayanan Perpustakaan dan Referensi untuk

Perpustakaan Sekolah. Bandung: Biro IKIP.

NS, Sutarno. (2006). Manajemen Perpustakaan. Jakarta, Sagung Seto.

Nurhadi, M. A, et al. (1980). Pedoman Pelayanan Sirkulasi dan Referensi Perpustakaan Perguruan Tinggi. Jakarta: Dep. P dan K.

Sumardji, P. (1992). Pelayanan Referensi di Perpustakaan. Yogyakarta: Kanisius.
Sasmitamiharja, I. D. (1988). Langkahlangkah Menuju Pelayanan Perpustakaan. Pembimbing Pembaca.

Widyawan, R. (2012). Pelayanan Referensi Berawal dari Senyuman. Bandung: Bahtera Ilmu. 